\section{Short-acting neuromuscular blocking drugs allow better control of OR time}

To the Editor:

I read with interest the article by Dahaba and colleagues comparing rocuronium and mivacurium equi-lasting doses in patients undergoing laparoscopic gynecological surgery. ${ }^{1}$ As the authors stated, the duration of this type of surgery is extremely variable. Since mivacurium is hydrolyzed by plasma cholinesterase the recovery time from the blockade does not depend on the total cumulative dose by either repeated doses or continuous infusion. ${ }^{2}$ It only depends on the presence of normal functioning plasma cholinesterase. This feature makes it unique especially when the duration of surgery is unpredictable. Stopping the infusion or maintenance dose administration at any time will be followed immediately by a fast recovery. In contrast, if the surgery is concluded immediately after a maintenance dose of rocuronium, a longer time will be needed for full recovery even if a reversal drug is given. Reid $e t a l$. found that after neostigmine reversal of rocuronium-induced neuromuscular blockade when $\mathrm{Tl}$ was $25 \%$, only 14 out of 40 patients attained a train-of-four ratio of 0.8 within 15 min of reversal administration. ${ }^{3}$ The difference in drug acquisition costs according to the authors was only 2 /patient in favour of rocuronium but the difference in recovery times (six minutes) was $45 /$ patient in favour of mivacurium. Even if we agree on the difference the authors reported in the recovery times, mivacurium use still costs 43 less/patient. If we add to this the frustration, that may result from delaying the operating room (OR) schedule, which will affect the next patient in the schedule, the surgeon, the nursing team as well as the anesthesiologist himself, we can conclude that mivacurium allows better control of OR time avoiding delays in patient recovery and its associated economic and personnel implications.

Mohammad El-Orbany MD

Chicago, Illinois

\section{References}

1 Dahaba AA, Schweitzer E, Fitzgerald RD, Schwarz S. Equi-lasting doses of rocuronium, compared to mivacurium, result in improved neuromuscular blockade in patients undergoing gynecological laparoscopy. Can J Anesth 2001; 48: 1084-90.

2 Savarese JJ, Lien CA, Belmont MR, Rubin L. The clinical and basic pharmacology of mivacurium: a shortacting nondepolarizing benzylisoquinolinium diester neuromuscular blocking drug. Acta Anesthesiol Scand
Suppl 1995; 106: 18-22.

3 Reid JE, Breslin DS, Mirakhur RK, Hayes AH.

Neostigmine antagonism of rocuronium block during anesthesia with sevoflurane, isoflurane or propofol. Can J Anesth 2001; 48: 351-5.

\section{REPLY:}

One out of 40 Caucasians are heterozygous for the atypical and the silent plasma cholinesterase gene, while one out of 2,800 are homozygous for the atypical gene. In these patients, neuromuscular blockade with mivacurium will be prolonged markedly, may last up to ten hours ${ }^{l}$ and could prove hard to reverse even with several doses of neostigmine. ${ }^{2}$ This would represent, in our hospital, an additional postanesthesia care unit or intensive care unit cost of \$4,500-\$9,000. It is likely that most anesthesiologists, in the course of their career, will encounter several cases of prolonged response to mivacurium (5-7\% of patients of an unselected population). ${ }^{3}$ Needless to say that accelerating the reversal of such a block using plasmacholinesterase derived from pooled human blood, with the inherent risk of infectious disease transmission, is not desirable. Screening all patients for abnormal plasma cholinesterase is not a practical solution as it is too expensive and time-consuming. ${ }^{4}$

In our discussion, we presented drug acquisition costs separately from the cost of running our operating room, which would obviously vary greatly between different hospitals. We feel strongly that decisions regarding time and cost should be left entirely to the discretion of each anesthesiologist who might, for instance, choose to avoid the costs associated with delayed mivacurium recovery. Others would choose to resort to a neuromuscular blocking drug infusion, as Dr. El-Orbany mentioned, or reversal of a residual mivacurium block although it might increase the risk of postoperative nausea and vomiting in gynecological laparoscopy. ${ }^{5}$ However, these considerations were beyond the scope and design of our study.

Ashraf A. Dahaba MD MSc

Graz, Austria

\section{References}

1 Viby-Mogensen J. Mivacurium block in patients with abnormal plasma cholinesterase. Acta Anaesthesiol Scand 1995; 39: 1001-2.

2 Petersen RS, Bailey PL, Kalameghan R, Ashwood ER. Prolonged neuromuscular block after mivacurium. Anesth Analg 1993; 76: 194-6.

3 Hanel HK, Viby-Mogensen J, de Muckadeel OB. Serum cholinesterase variants in the Danish population. Acta Anaesthesiol Scand 1978; 22: 505-7.

4 Maddineni VR, Mirakhur RK. Prolonged neuromus- 